\title{
Economic assessment of Holstein-Friesian dairy cows of divergent Economic Breeding Index evaluated under seasonal calving pasture-based management
}

\author{
M. O'Sullivan, ${ }^{1,2} \odot$ L. Shalloo, ${ }^{1} \odot$ K. M. Pierce, ${ }^{2} \odot$ and F. Buckley ${ }^{1,2 *}$ \\ ${ }^{1}$ Animal and Grassland Research and Innovation Centre, Teagasc Moorepark, Fermoy, Co. Cork, P61 C997 Ireland \\ ${ }^{2}$ School of Agriculture and Food Science, University College Dublin, Belfield, Dublin, D04 N2E5 Ireland
}

\begin{abstract}
The objective of this study was to investigate the economic performance of 2 genetic groups (GG) of Holstein-Friesian dairy cows of divergent Economic Breeding Index (EBI), evaluated within 3 contrasting spring-calving pasture-based feeding treatments (FT). The study was a simulated economic appraisal, using the Moorepark Dairy Systems Model, a stochastic budgetary simulation model integrating biological data obtained from a 4-yr experiment conducted from 2013 to 2016. The 2 divergent GG were (1) high EBI representative of the top 5\% nationally (elite) and (2) EBI representative of the national average (NA). The 3 FT were reflective of slight restriction to generous feeding. The elite GG had the lowest replacement rate, and therefore had lower replacement costs and an older and more productive parity structure. The elite GG consistently had higher sales of milk (on average $+3 \%$ or $+18,370 \mathrm{~kg}$ of milk) and milk solids (milk fat plus protein yield; $+8.7 \%$ or $+4,520 \mathrm{~kg}$ ) compared with the NA GG across the 3 FT scenarios. Milk income was consequently greater for elite versus NA (on average $+9.5 \%$ or $+€ 21,489)$ cows. Livestock sales were greater (on average $+13.2 \%$ or $+€ 4,715$ ) for NA compared with elite cows. Baseline net farm profit and net profit/ ha at a base milk price of 29.5 cents per liter $(3.3 \%$ protein and $3.6 \%$ fat) were on average $€ 31,156$, and $€ 772$ greater for elite compared with NA cows across the 3 FT. Greater profitability achieved with elite cows in each of the FT investigated demonstrated the adaptability of high-EBI cows across different levels of feeding intensities in seasonal pasture-based feeding systems. Sensitivity analysis of varying milk price and concentrate cost did not result in a reranking of GG for farm profit. This study clearly demonstrates the power of a suitably constructed genetic-selection index together with a well-considered breeding program to
\end{abstract}

Received September 4, 2019.

Accepted July 9, 2020.

*Corresponding author: Frank.Buckley@teagasc.ie deliver genetics capable of favorable change to farm physical performance and profit over a relatively short duration.

Key words: replacement cost, profitability

\section{INTRODUCTION}

Pasture-based systems of milk production are commonly practiced in New Zealand, Latin America, parts of the United States, and various parts of Europe (Washburn and Mullen, 2014). Milk production in both Ireland and New Zealand is based predominantly on a seasonal calving pasture-based system where the primary feed source of lactating dairy cows is grazed grass (Shalloo et al., 2004a; Dillon et al., 2005; Hanrahan et al., 2018), which typically comprises $>82 \%$ of the diet (O'Brien et al., 2018). Irrespective of location, the goals of pasture-based producers are generally similar: to match pasture resources with the nutritional requirements of the herd (Washburn and Mullen, 2014). Hence, the relative importance of fertility is greater in seasonal systems of milk production compared with nonseasonal systems to maximize the use of low-cost grazed grass in the diet of the lactating cow (Veerkamp et al., 2002; Shalloo et al., 2014). In addition, the challenges presented by pasture-based systems are universal, including energy expenditure associated with grazing activity (Dohme-Meier et al., 2014), variability in seasonal weather conditions, and a fluctuating feed supply both in terms of availability and quality (Bargo et al., 2003; Van Vuuren and Van den Pol-van Dasselaar, 2006). Therefore, the identification of appropriate genetics for pasture-based systems is a prerequisite to achieving optimal physical and economic efficiency. There is a requirement that resilient animals capable of efficient production of milk solids (predominantly from pasture) combined with high fertility performance are selected (Washburn and Mullen, 2014; Delaby et al., 2018).

The Irish dairy industry has an export-orientated product mix, of which over $90 \%$ is exported internationally (Geary et al., 2010). Given the associated dynamics of volatility in world dairy commodity prices 
(Keane and O'Connor, 2009), business success in an environment with a lower and more volatile milk price requires pasture-based producers to become more focused on maximizing efficiency (Shalloo et al., 2011; Hanrahan et al., 2018) and ensuring business resilience (Shadbolt, 2012). Herein lies the challenge for producers. Although Ireland is considered one of the most competitive milk producers worldwide (HurtadoUria et al., 2013), further increases in efficiency and profitability can be achieved at the farm level through improvements in dairy cow fertility, productivity, and increased grass use (Shalloo et al., 2014). Prior to the early 2000s in Ireland, the lack of a dedicated national dairy breeding program resulted in a reliance upon imported genetics from international breeding programs, the objectives of which were not aligned with the needs of seasonal pasture-based milk production. Potential increases in profitability as a result of increased cow milk production were not realized due to high reproductive wastage (Evans et al., 2006b). The introduction of balanced genetic selection for production and fertility using the Economic Breeding Index (EBI) in 2001, national progeny testing of indigenously sourced genetics in 2005, and the incorporation of genomic selection in 2009 has culminated in rapid rates of genetic gain (ICBF 2018). In the meantime, selection objectives have also evolved internationally, incorporating fertility, health, and fitness traits (Miglior et al., 2017; Cole and Van Raden, 2018). However, periodic evaluation of breeding goals is prudent to validate genetic gain and ensure the compatibility of resultant genetics with the production system (O'Sullivan et al., 2019a) and to test the effect on the efficiency of the system as a whole.

The "Next Generation Herd" was established at Teagasc, Moorepark as a sentinel research herd to evaluate anticipated phenotypic performance and profitability of futuristic genetics selected on EBI. Already published performance results indicate favorable genetic gain for milk solids yield (O'Sullivan et al., 2019a), intake capacity and energy balance (O' Sullivan et al., 2019b), reproductive efficiency, and longevity (O'Sullivan et al., 2020) with very high-EBI cows compared with cows of average EBI (O'Sullivan et al., 2020). To estimate the economic effect of selection for EBI at the commercial farm level, a systems approach is required that integrates and extrapolates the biological experimental data to create a simulated commercial farm scenario and incorporates all major farm components, including production revenues and both variable and fixed costs. Therefore, the objective of this study was to simulate an economic appraisal of 2 genetic groups $(\mathbf{G G})$ of Holstein-Friesian (HF) dairy cows of divergent EBI across 3 contrasting spring-calving pasture-based feeding treatments (FT) using the Moorepark Dairy Sys- tems Model, a stochastic budgetary simulation model integrating biological data obtained from a 4-yr experiment conducted during 2013 to 2016.

\section{MATERIALS AND METHODS}

\section{Study Details}

Briefly, the Next Generation Study herd was located at the Dairygold Research Farm (Teagasc, Animal and Grassland Research and Innovation Centre, Moorepark, Ireland; $\left.52^{\circ} 09^{\prime} \mathrm{N} ; 8^{\circ} 16^{\prime} \mathrm{W}\right)$. Two GG were compared: high EBI, representative of the top $5 \%$ of Irish dairy cows ranked on EBI (elite), and cows representative of the national average genetic merit (NA), outlined in detail by O'Sullivan et al. (2019a). The mean EBI and EBI subindex values for milk, fertility, calving, beef, maintenance and health, and PTA for calving interval and survival for the elite and NA cows (excluding the influence of both own and progeny performance) are presented in Table 1 (ICBF, 2018). In each year, 90 elite and 45 NA cows were randomly assigned to 1 of 3 experimental FT. Both GG were balanced for parity and calving date each year. The 3 experimental FT were control (CTL), high concentrate (HC), and lower grass allowance (LGA), characterized by target postgrazing compressed sward heights of 4.5 to $5 \mathrm{~cm}, 4.5$ to $5 \mathrm{~cm}$, and 3.5 to $4 \mathrm{~cm}$, and planned concentrate allowances of $300,1,100$, and $300 \mathrm{~kg} / \mathrm{cow}$ per year, respectively. The $3 \mathrm{FT}$ were designed to determine genetic expression across pasture-based scenarios representative of upper and lower limits of recommended best practices to maximize productivity per cow and per hectare in Irish milk production systems ( $\mathrm{O}^{\prime}$ Donovan et al., 2011). The CTL and HC FT allowed each GG to express its potential within each FT largely unrestricted by limitations in feed supply, while the LGA FT allowed each GG to express its potential within each FT under lower grass allowance. Details of the realized pasture management and grass quality were reported by O'Sullivan et al. (2019a) and O'Sullivan et al. (2019b), respectively. Once treatments were implemented, paddock residency time was determined by the achievement of the predefined target postgrazing residual sward heights for each FT. Grass growth and availability on each paddock was recorded weekly within the PastureBase Ireland grassland decision support system (Hanrahan et al., 2017). Pasture was managed as per the recommendations of O'Donovan (2000), with surplus grass conserved as grass silage. Details of the pasture management and grass quality were reported by O'Sullivan et al. (2019a). The CTL and LGA were offered a pasture-only diet from the date upon which FT were implemented. Thereafter, concentrate was 
Table 1. The mean Economic Breeding Index (EBI), EBI subindices, and PTA for milk production traits of the 2 genetic groups of Holstein-Friesian studied

\begin{tabular}{|c|c|c|c|c|}
\hline \multirow[b]{2}{*}{ Item } & \multicolumn{4}{|c|}{ Genetic group $^{1}$} \\
\hline & Elite & SD & NA & $\mathrm{SD}$ \\
\hline $\mathrm{EBI}(€)$ & 154 & \pm 34.2 & 47 & \pm 30.9 \\
\hline \multicolumn{5}{|l|}{ Subindex } \\
\hline Milk (€) & 28 & \pm 20.0 & 7 & \pm 17.5 \\
\hline Fertility $(€)$ & 103 & \pm 28.9 & 28 & \pm 22.7 \\
\hline Calving (€) & 31 & 8.0 & 24 & \pm 8.6 \\
\hline Beef $(€)$ & -21 & \pm 7.6 & -13 & \pm 8.0 \\
\hline Maintenance $(€)$ & 12 & \pm 8.5 & 2 & \pm 8.9 \\
\hline Health $(€)$ & 0 & \pm 4.6 & -1 & \pm 4.6 \\
\hline \multicolumn{5}{|l|}{ PTA } \\
\hline Milk (kg) & -52.0 & \pm 132.6 & 0.6 & \pm 127.4 \\
\hline Fat $(\mathrm{kg})$ & 6.9 & \pm 5.08 & 3.4 & \pm 4.15 \\
\hline Protein (kg) & 2.5 & \pm 3.73 & 0.5 & \pm 3.42 \\
\hline Fat $(\%)$ & 0.17 & \pm 0.110 & 0.07 & \pm 0.094 \\
\hline Protein (\%) & 0.13 & \pm 0.054 & 0.05 & \pm 0.045 \\
\hline
\end{tabular}

${ }^{1}$ Elite $=$ high EBI; NA = national average EBI.

introduced for short periods to alleviate grass supply deficits only, with the differential of $4 \mathrm{~kg}$ in concentrate allocation between HC and both CTL and LGA maintained throughout.

\section{Economic Analysis}

To evaluate the economic efficiency of alternative GG and FT combinations, a comprehensive multidisciplinary system approach was required. The Moorepark Dairy Systems Model (MDSM; Shalloo et al., 2004a), a stochastic budgetary simulation model, was used to simulate a model farm, integrating biological data for each GG in each FT. The model integrated animal inventory and valuation, milk production, feed requirement, land, labor, and variable and fixed costs. Variable costs (including fertilizer, contractor charges, medical and veterinarian, AI, silage, reseeding), fixed costs (machinery maintenance and running costs, farm maintenance, car, telephone, electricity, depreciation, insurance), and revenue (milk, calf, and cull cow) were based on current prices and costs. The economic analysis was based on a 40-ha farm carrying 110 cows, where additional forage was purchased when required to fill any deficit in feed demand at a cost of $€ 160 / t$. The feeds offered (pasture, silage, and concentrate) were determined by the MDSM, meeting the cow's energy requirements for maintenance, milk production, pregnancy, BCS change, and BW change (Jarrige, 1989). The key herd default assumptions used in the model farm are outlined in Table 2. Concentrate was assumed to cost $€ 280 /$ t. Base milk price was 29.5 cents per liter plus value-added tax of $5.4 \%$ for milk, assuming reference milk content of $36.0 \mathrm{~g} / \mathrm{kg}$ of fat and $33.0 \mathrm{~g} / \mathrm{kg}$ of protein, and a relative milk-price ratio for fat to protein of 1:1.5. It was assumed that all calves were fed $4 \mathrm{~L}$ of whole milk per day and were sold from the farm at 4 wk of age. Male calves were assumed sold for a market value of $€ 80$. Heifer calves were assumed sold for a market value of $€ 350$. Replacement females were purchased 1 mo before calving at an estimated cost of $€ 1,545$ each (Shalloo et al., 2014). Cull cow values (weighted for parity structure) were based on BW at the end of lactation, an assumed kill-out rate $(45 \%)$ based on the findings of Minchin et al. (2009), and carcass value of $€ 2$ per kg. Cull cows were assumed to have left the farm as they stopped milking; a small number of animals left during the year, and the bulk of animals left at the end of lactation. It was assumed that there was no feeding period included for these animals. Labor costs were estimated at $€ 15.00 / \mathrm{h}$ and labor requirements were $30.0 \mathrm{~h} / \mathrm{cow}$ per year. Labor requirement was divided between time associated with the cow and other farm tasks (milking, grassland management, maintenance, calf care, cleaning, veterinary, and miscellaneous).

The milk production, reproductive performance, and calving pattern of both GG from the 4-yr experiment

Table 2. Financial and biological assumptions used in the Moorepark Dairy Systems Model

\begin{tabular}{ll}
\hline Item & Assumption \\
\hline Farm size $($ ha) & 40 \\
Price fat to protein ratio & $1: 1.5$ \\
Replacement heifer price $(€)$ & 1,545 \\
Labor costs $(€ / \mathrm{h})$ & 15.00 \\
Prices and costs in 2019 & \\
Reference cull cow price $(€ / \mathrm{kg}$ carcass $)$ & 2.00 \\
Reference male calf price $(€)$ & 80 \\
Concentrate costs $(€ / \mathrm{t}$ as fed) & 280 \\
Silage costs $(€ / \mathrm{t}$ of $\mathrm{DM})$ & 160 \\
Housing costs $(€ /$ cow $)$ & 1,500 \\
\hline
\end{tabular}


Table 3. Effect of genetic group (GG) of Holstein-Friesian on herd parity structure

\begin{tabular}{lcc}
\hline & \multicolumn{2}{c}{$\mathrm{GG}^{1}$} \\
\cline { 2 - 3 } $\begin{array}{l}\text { Parity structure } \\
\text { number of cows) }\end{array}$ & Elite & NA \\
\hline Parity 1 & 18 & 28 \\
Parity 2 & 15 & 21 \\
Parity 3 & 13 & 16 \\
Parity 4 & 64 & 46 \\
\hline
\end{tabular}

${ }^{1}$ Elite $=$ high Economic Breeding Index; $\mathrm{NA}=$ national average Economic Breeding Index.

(O'Sullivan et al., 2019a, 2020) were used to parameterize the model. Milk yield was adjusted for the parity structure, while milk fat, protein, and lactose concentrations were as observed by O'Sullivan et al. (2019a). Replacement rate was the proportion of cows that failed to become pregnant (involuntary culling) by the end of the breeding season plus a voluntary culling rate of $10 \%$ of the remaining animals. Fertility performance did not differ significantly between FT during the 4-yr systems study (O'Sullivan et al., 2020); therefore, all 3 FT were assumed to have the same replacement rate in the model. Pasture growth rates, sward quality, and use efficiency were inputted to the model, with the model calculating feed demand based on the descriptions above. Any calculated feed deficits were assumed to be filled with silage purchased at a cost of $€ 160 / t$ of DM.

Sensitivity analysis was undertaken to investigate the effect of differences in milk price and fluctuations in concentrate cost on the anticipated net profit of the various GG and FT combinations. The GG were compared with base milk prices consisting of 5.0 cents per liter above and below the base price of 29.5 cents per liter. We also investigated the effect of an increase and decrease in concentrate cost by $€ 50 / t$ on profitability of the various $\mathrm{GG}$ and $\mathrm{FT}$ combinations.

\section{RESULTS}

\section{Milk Production and Fertility Performance}

The parity structure of the simulated elite and NA herds in this analysis is outlined in Table 3 . The elite GG had the lowest replacement rate, and therefore a lower proportion of animals were in parity 1,2 , and 3 , and a greater proportion of animals survived to parity 4 or greater when compared with NA. Milk production and BW data simulated based on the calculated herd parity structure over the 4-yr experimental period are outlined in Table 4. On average, milk yield and milk solids yield were greater with elite cows $(+117$ and +36 $\mathrm{kg} /$ cow, respectively) compared with NA across the 3 FT. There was an increase in milk production per cow from LGA to CTL to HC.

\section{Model Outputs}

The key herd output parameters from the model for all GG and FT combinations on a 40-ha farm are outlined in Tables 5 and 6 . Total milk and milk solids sales were greater for elite cows compared with NA cows within each FT. Total milk and milk solids sales increased from LGA to CTL to HC FT in accordance with the differential in feeding associated with each FT. Total milk sales were on average $3 \%(18,370 \mathrm{~kg}$ of milk) greater, and total milk solids sales were on average $8.7 \%(4,520 \mathrm{~kg}$ of milk solids) greater for elite herds compared with NA herds across the 3 FT. Total pasture production, based on weekly recording of pasture availability on each paddock (O' Sullivan et al., 2019a), was assumed similar for all $3 \mathrm{FT}$. The proportion of silage purchased was greater in the CTL FT (34.4 t) compared with the LGA $(6.6 \mathrm{t})$ and HC FT (1.8 t). The total dairy cow feed budget was 1.1, 4.7, and 3.0\%

Table 4. Effect of genetic group ${ }^{1}$ of Holstein-Friesian and feeding treatment ${ }^{2}$ (FT; CTL, HC, LGA) on milk production and BW

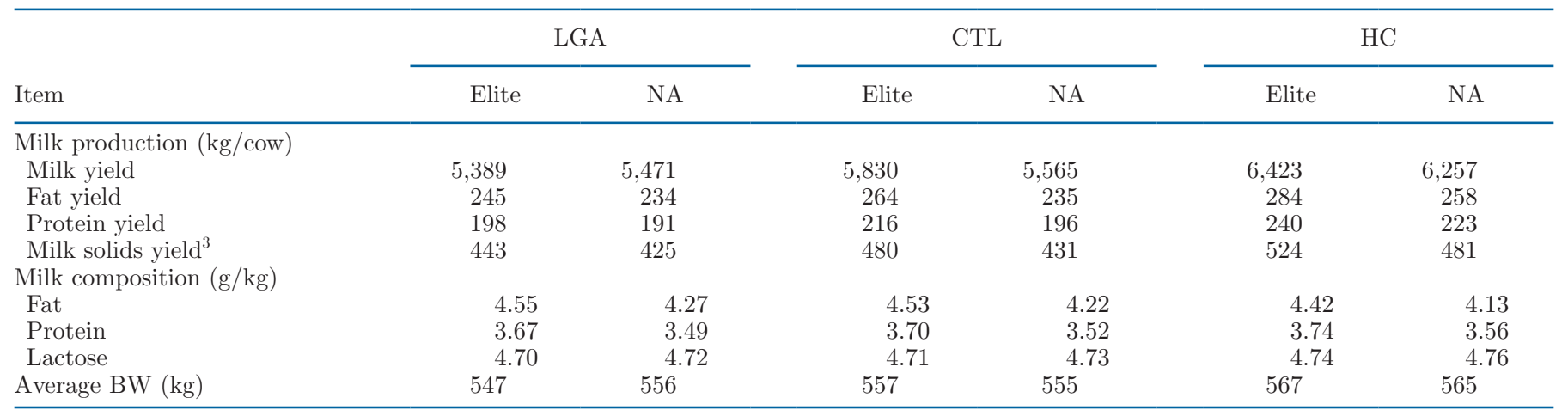

${ }^{1}$ Elite $=$ high Economic Breeding Index; NA = national average Economic Breeding Index.

${ }^{2} \mathrm{CTL}=$ high grass allowance $\mathrm{FT} ; \mathrm{HC}=$ high concentrate $\mathrm{FT} ; \mathrm{LGA}=$ lower grass allowance FT.

${ }^{3}$ Milk solids $=$ fat $(\mathrm{kg})+$ protein $(\mathrm{kg})$. 
Table 5. Effect of genetic group ${ }^{1}$ of Holstein-Friesian and feeding treatment ${ }^{2}$ (FT; CTL, HC, LGA) on physical model outputs on a 40-ha farm

\begin{tabular}{|c|c|c|c|c|c|c|}
\hline Item & \multicolumn{2}{|c|}{ LGA } & \multicolumn{2}{|c|}{ CTL } & \multicolumn{2}{|c|}{$\mathrm{HC}$} \\
\hline Cows & 110 & 110 & 110 & 110 & 110 & 110 \\
\hline Milk sold ( $\mathrm{kg}$ ) & 580,646 & 583,726 & 629,596 & 597,366 & 695,156 & 669,196 \\
\hline Milk solids ${ }^{3}$ sales $(\mathrm{kg})$ & 47,793 & 45,316 & 51,984 & 46,164 & 56,791 & 51,527 \\
\hline Fat $(\mathrm{kg})$ & 26,465 & 24,856 & 28,595 & 25,122 & 30,702 & 27,630 \\
\hline Grass used (kg of DM/ha) & 14,028 & 13,484 & 13,765 & 12,620 & 13,341 & 12,394 \\
\hline Imported silage ( $\mathrm{kg}$ of $\mathrm{DM})$ & 6,269 & 6,853 & 35,807 & 33,000 & 2,453 & 1,190 \\
\hline \multicolumn{7}{|l|}{ Feed budget ( $\mathrm{kg}$ of $\mathrm{DM} / \mathrm{cow}$ ) } \\
\hline Grass & 3,733 & 3,675 & 3,956 & 3,715 & 3,696 & 3,512 \\
\hline Silage & 1,204 & 1,206 & 971 & 968 & 1,088 & 1,092 \\
\hline Concentrate & 318 & 316 & 315 & 314 & 1,116 & 1,102 \\
\hline Total feed & 5,255 & 5,197 & 5,243 & 4,996 & 5,900 & 5,706 \\
\hline
\end{tabular}

${ }^{1}$ Elite $=$ high Economic Breeding Index; NA = national average Economic Breeding Index.

${ }^{2} \mathrm{CTL}=$ high grass allowance $\mathrm{FT} ; \mathrm{HC}=$ high concentrate FT; LGA = lower grass allowance FT.

${ }^{3}$ Milk solids $=$ fat $(\mathrm{kg})+$ protein $(\mathrm{kg})$.

greater with elite cows compared with NA cows in the LGA, CTL, and HC FT, respectively, as a consequence of the greater energy requirements associated with greater milk solids production of elite cows within each of the respective FT. The total feed requirements per cow was on average $167 \mathrm{~kg}(3.1 \%)$ greater for elite cows compared with NA cows.

Production income and costs for all GG and FT are outlined in Table 6. Total production income (milk returns plus livestock sales) were greater with elite compared with NA for each of the 3 FT. Milk returns were on average $9.5 \%(€ 21,489)$ greater for elite cows than NA cows across the $3 \mathrm{FT}$, and livestock sales were $13.2 \%(€ 4,715)$ greater for NA cows compared with elite cows. Replacement rate was $10 \%$ lower with elite cows (18\%) than NA cows (28\%) and resulted in lower replacement costs with elite compared with NA cows. Total production costs were on average 8.5\% (€13,324) greater with NA cows compared with elite cows across the 3 FT. The increase in total production costs observed with NA cows is reflective of the higher replacement rate and higher replacement costs with NA cows.

Table 6. Effect of genetic group ${ }^{1}$ of Holstein-Friesian and feeding treatment ${ }^{2}$ (FT; CTL, HC, LGA) on economic model outputs on a 40-ha farm

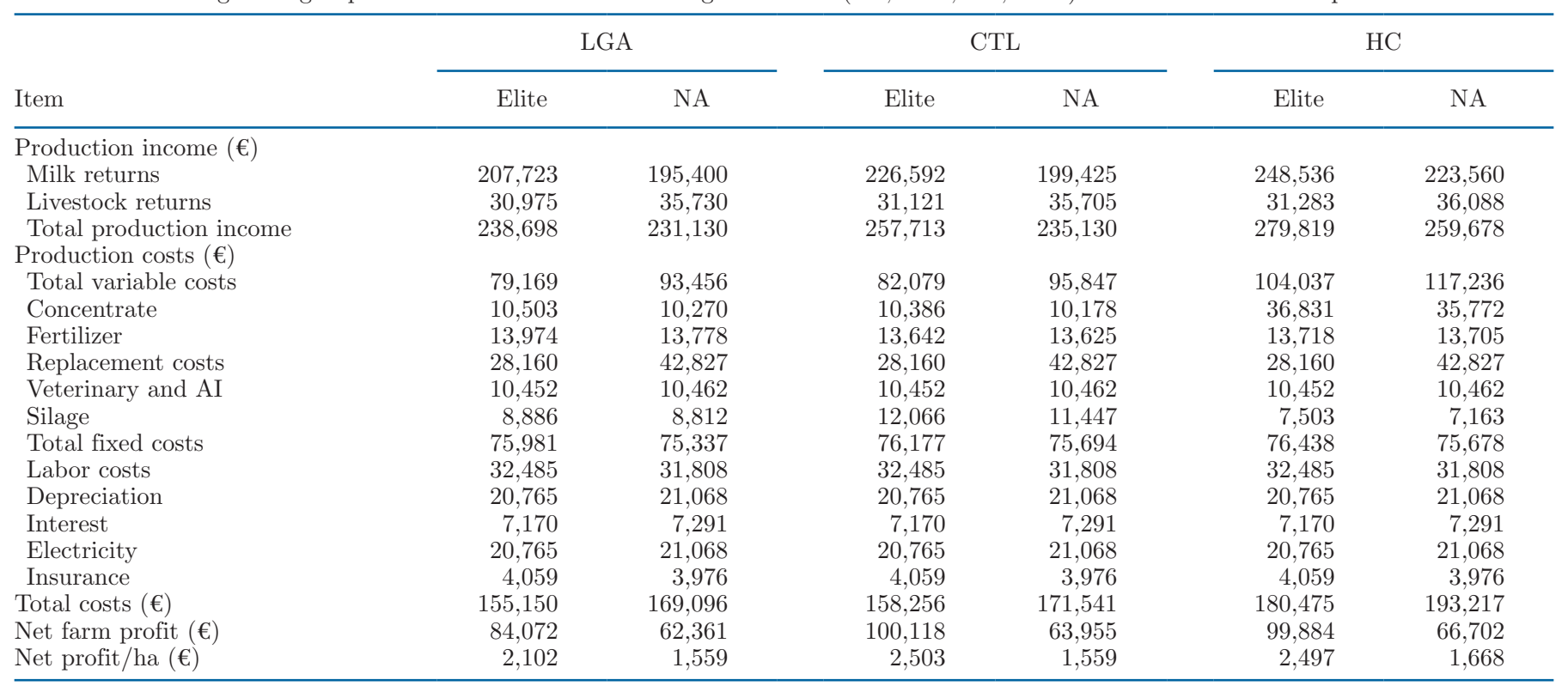

${ }^{1}$ Elite $=$ high Economic Breeding Index; NA = national average Economic Breeding Index.

${ }^{2} \mathrm{CTL}=$ high grass allowance $\mathrm{FT} ; \mathrm{HC}=$ high concentrate FT; LGA = lower grass allowance FT. 
Table 7. Effect of genetic group ${ }^{1}$ of Holstein-Friesian and feeding treatment ${ }^{2}$ (FT; CTL, HC, LGA) on net profit at varying milk prices and concentrate costs

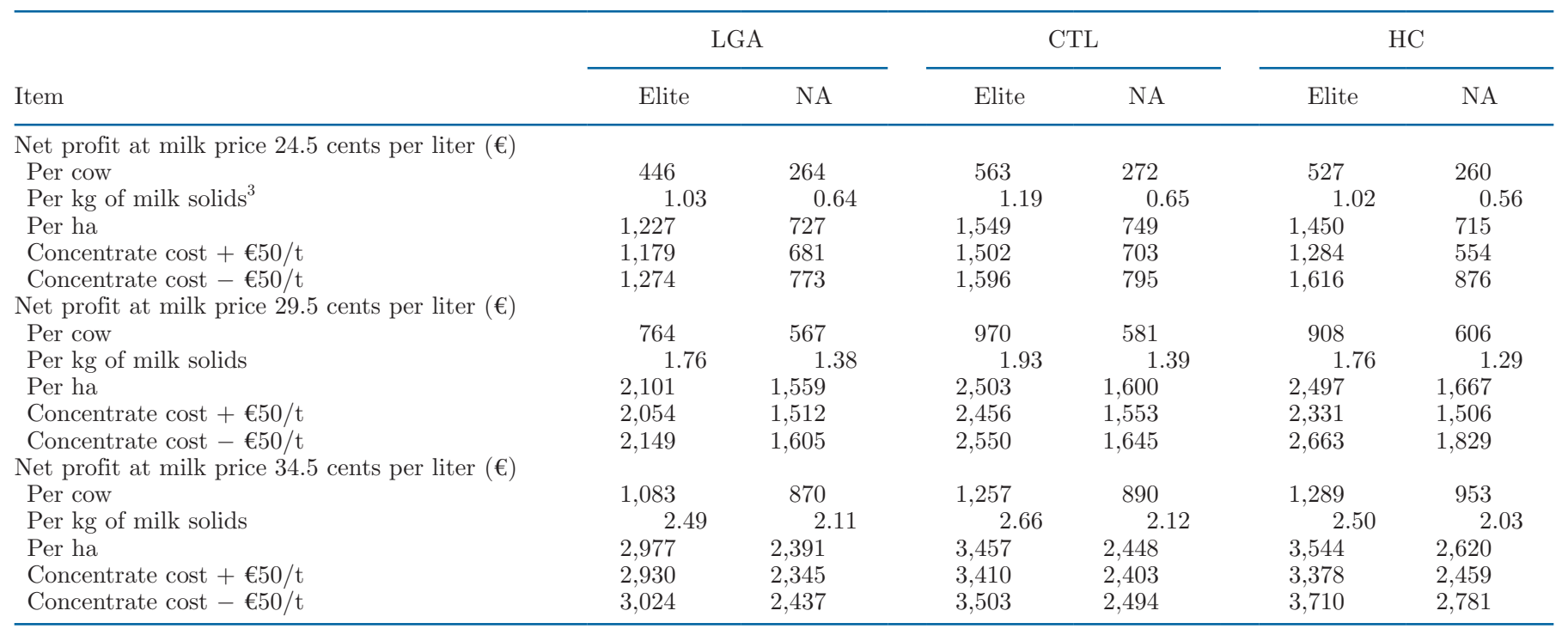

${ }^{1}$ Elite $=$ high Economic Breeding Index; NA = national average Economic Breeding Index.

${ }^{2} \mathrm{CTL}=$ high grass allowance $\mathrm{FT} ; \mathrm{HC}=$ high concentrate FT; LGA = lower grass allowance FT.

${ }^{3}$ Milk solids $=$ fat $(\mathrm{kg})+$ protein $(\mathrm{kg})$.

Total production costs were similar between LGA and CTL FT; however, total production costs were greatest with the HC FT, reflecting the cost of additional concentrate feed purchased in this feeding treatment. As the quantity of fertilizer spread was similar for each of the $3 \mathrm{FT}$, fertilizer costs were similar for all $3 \mathrm{FT}$. Silage making and the requirement for purchased silage was greatest in the CTL FT. Fixed costs were similar for each GG across the $3 \mathrm{FT}$. Baseline net farm profit and net profit per hectare at 29.5 cents per liter were on average €30,356 and €772 greater for elite compared with NA across the $3 \mathrm{FT}$. Baseline profit per cow was $€ 276$ greater with elite cows compared with NA across the 3 FT.

\section{Sensitivity Analysis}

Net profit obtained at various milk prices $(24.5,29.5$, and 34.5 cents per liter) and expressed in euros per cow, euros per kilogram of milk solids, and euros per hectare, are outlined in Table 7 . The effect of a $€ 50$ increase or decrease in concentrate cost is also derived. At all milk prices, net profit per cow, per kilogram of milk solids, and per hectare was greatest with elite cows within each of the FT. There was a large increase in profitability moving from LGA to CTL FT at all 3 milk prices. There was little difference in profitability at 29.5 and 34.5 cents per liter between CTL and HC; however, at 24.5 cents per liter, CTL was more profitable than HC. When concentrate cost increased by $€ 50$, from $€ 280$ to $€ 330 /$ t, the CTL FT was more profitable; at a $€ 50$ reduction in concentrate cost from $€ 280$ to $€ 230 / t$, the difference in profitability between CTL and HC FT was minimal.

\section{DISCUSSION}

Productivity within seasonal pasture-based systems is generally limited by pasture production and use (Holmes et al., 2002; Shalloo, 2009; Hanrahan et al., 2017), which is reliant upon compact calving pattern (driven by reproductive performance of the dairy herd; Shalloo et al., 2014). Genetic improvement of the dairy herd in combination with improved management practices have been identified as principal routes to the achievement of increased economic efficiency of such systems (Veerkamp et al., 2002; Dillon et al., 2008). The current study provided a unique opportunity to evaluate the economic effect of elite cows selected based on a high EBI compared with NA cows within contrasting feeding-management scenarios. The economic appraisal, through simulation with a model parameterized with actual experimental data from a controlled environment, is essential to determine likely economic effects at the farm level. While other studies have shown associations (Ramsbottom et al., 2012), no definitive cause and effect can be attributed in that study because the EBI effect cannot be definitively separated from the operator. The approach of this study overcame that issue. 


\section{The Effect of GG on Economic Performance}

Traditionally, genetic-selection programs have focused on increased milk production (Miglior et al., 2005), with a consequent reduction in dairy cow fertility observed at the commercial farm level in Ireland (Evans et al., 2006a) and globally (Lucy, 2001; Macdonald et al., 2008). Reproductive performance affects the amount of milk produced per cow per day of herd life, diet within a pasture-based system, age profile of the herd, breeding costs, rate of voluntary and involuntary culling, and rate of genetic progress for traits of economic importance (Plaizier et al., 1997), while optimal financial performance arises with an involuntary culling rate of approximately 7\% (Esslemont et al., 2001). Evans et al. (2006b) showed that as a consequence of past genetic selection exclusively for greater milk production, approximately half of the potential gains in profitability from increased herd production, were not realized on commercial dairy farms in Ireland due to a deterioration in fertility performance. Even though there was increased milk yield potential within herds, the associated reduction in fertility performance meant that the economic performance of the animals was static. The results of the present study showed that within each of the pasture-based FT scenarios investigated, greater profitability was realized with high-EBI cows, which combined production potential for high value milk solids with excellent levels of reproductive efficiency and longevity. O'Sullivan et al. (2019a) previously showed higher milk solids production with elite cows. The superior fertility and longevity of elite cows reported by O'Sullivan et al. (2020) resulted in a lower replacement rate, and consequently a higher proportion of mature cows in elite herds compared with NA herds in this economic simulation. This further enhanced herd milk production, and thus greater milk returns. A difference of $8 \mathrm{~kg}$ of milk solids per cow in favor of elite cows compared with NA was observed in the study of O'Sullivan et al. (2019a), in which differences in parity structure were controlled for. The unique benefit of the present economic simulation is that it served to determine likely economic effects at the commercial farm level, specifically the identification of the parity structure of both elite and NA herds based on the experimental fertility differences reported by O'Sullivan et al. (2020) under commercial farm circumstances where herd fertility performance dictated herd parity structure. In the present economic simulation, fertility differences between the GG contributed to a $10 \%$ difference in replacement rate, thus the difference observed in milk solids production was on average $+36 \mathrm{~kg}$ of milk solids in favor of elite across the $3 \mathrm{FT}$. In addition, the large difference in total costs between elite and NA herds was a result of significantly lower replacement rate and costs with elite cows, reinforcing the significance of reproductive capacity within pasture-based systems (Schmidt, 1989; Plaizier et al., 1997) and its role in reducing total farm costs (Shalloo et al., 2014).

Increasing levels of volatility in milk and feed prices has led to higher levels of market and financial risk for dairy farmers (Wolf and Olynk Widmar, 2014). Volatility in farm-gate milk price has become a feature of Irish milk production systems over the past decade (Loughrey et al., 2015), and will continue to be into the future. The increased levels of milk price volatility and the subsequent cash flow pressures placed on farms require a complete refocus on farm efficiency and, in particular, business resilience (Shadbolt, 2012). Reducing the cost of production is a key opportunity available to dairy farmers to insulate against increased price volatility to enhance business resilience. The present economic analysis demonstrated that elite cows had increased fertility with excellent levels of productivity (fat plus protein yield), thus achieved lower total costs, greater total production income, and overall greater profitability than NA at all milk prices and concentrate costs investigated. Similar to the current study, previous studies have evaluated contrasting strains of HF (McCarthy et al., 2007) and alternative breeds and their respective crosses (Lopez-Villalobos et al., 2000; Evans et al., 2004; Prendiville et al., 2011) within a variety of pasture-based feeding systems. The common outcomes observed from these studies are increased profitability due to lower replacement rates and a greater proportion of cows surviving longer, thus higher herd productivity. Furthermore, the present analysis has demonstrated that the reduction in costs associated with reduced infertility and replacement can be achieved through genetic selection for high-EBI genetics.

Previous economic evaluation using commercial farm data of farm profitability and herd EBI (Ramsbottom et al., 2012) demonstrated that each $€ 1$ increase in herd EBI was associated with a $€ 2$ increase in net profit per cow. In commercial farm studies such as ours, it is difficult to isolate the effect of a single component of the system from the farmer; therefore, these types of studies are useful to provide an associative conclusion rather than making any statements about causation. In the present study, the controlled nature of the study made the analysis much clearer, with each unit increase in EBI associated with a $€ 2.58$ increase in profit per cow.

\section{The Effect of FT on Economic Performance}

In the context of pasture-based production systems, land is the limiting resource to productivity; therefore, 
optimizing output per hectare through increased pasture accumulation and use is pertinent to the sustainable intensification of grazing systems of animal production (Coffey et al., 2018). In contrast to previous studies whereby animals were evaluated under various stocking rates, the objective of the present study was to evaluate the effect of $2 \mathrm{GG}$ of $\mathrm{HF}$ dairy cows of divergent EBI across 3 contrasting spring-calving pasture-based FT. The FT in the present study were designed to represent management scenarios reflective of the upper and lower limits of recommended best practices to maximize productivity per hectare and per cow in Irish pasture-based milk production systems. Systems of milk production that incorporate higher levels of concentrate supplementation have traditionally been associated with increased costs of production and reduced profitability (Shalloo et al., 2004a; McCarthy et al., 2007) mainly due to increased substitution of concentrate for pasture and a consequent reduction in pasture use (Bargo et al., 2002; McEvoy et al., 2008). Previous studies have reported a decline in pasture eaten per cow when supplement is consumed (Bargo et al., 2003; Sheahan et al., 2011). Furthermore, Ramsbottom et al. (2012) observed that profitability of the dairy business declined, on average, with greater use of supplementary feeds in a study of commercial farm data. Internationally, studies using commercial farm data have reported similar findings (Kolver and Hedley, 2006; Shadbolt, 2012). The relatively moderate substitution rates of pasture for concentrate and the achievement of target postgrazing sward heights in both GG within the HC FT reported by O'Sullivan et al. (2019a) suggest that poorer use of pasture was not a causative factor for any potential reduction in profitability in the HC FT in this study. Greater profitability in systems that require less purchased supplement per cow is due to greater pasture harvest per hectare and reduced costs per cow and per hectare. Ultimately, these previous studies have indicated that, within a grazing system, farm management results in greater variability in profitability than the system of farming, as defined by intensity of feeding (Shadbolt, 2008). Therefore, at the commercial farm level, the varied levels of farm management infer a likelihood of reduced use of pasture where concentrate supplement is increased. The increased financial loss of HC FT in comparison with the CTL FT at lower milk prices and increased concentrate costs, and the increased farm profit of both elite and NA cows under $\mathrm{HC}$ at a base milk price of 34.5 cents per liter is consistent with the findings of previous studies (Shalloo et al., 2004b; McCarthy et al., 2007; Hanrahan et al., 2018). Shalloo et al. (2004b) postulated that in a high milk price scenario, increased use of low-cost concentrate supplementation could enhance profitability if a high response to concentrate supplementation (in excess of $1.1 \mathrm{~kg}$ of milk per kilogram of concentrate) is achieved. The response rate to concentrate supplementation reported by O'Sullivan et al. (2019a) for both GG approached the results postulated by Shalloo et al. (2004b); nevertheless, the response of both GG suggests limited potential to enhance profitability through increased concentrate supplementation. The economic analysis presented here substantiates this, as the profitability of the HC FT in the present study was broadly similar to that of the CTL FT at all milk price scenarios investigated. Differences in profitability between CTL and $\mathrm{HC}$ arose at a higher concentrate price. Hanrahan et al. (2018) reported significant increases in the costs of production and reduced profitability linked to supplementary feed, creating a strong argument against the excessive use of supplementary feed in grazing dairy systems. Therefore, to achieve high profitability, the priority of intensive pasture-based feeding systems, such as those implemented in the present study, must be to increase the level of use of pasture and focus on concentrate supplementation as a method of supporting the system when pasture shortages occur, rather than as a method to drive milk yield per cow. This differentiation is key to ensure that pasture use drops are minimized, that substitution is minimized, and that the overall system does not change when supplement is included. The implications of implementing feeding management such as the LGA is comparable to previous research whereby lower postgrazing residuals resulted in reduced milk production per cow (McCarthy et al., 2013), typical of what might be observed at higher farm stocking rates. Although output per cow is reduced at higher stocking rates, the objective is to increase milk solids per hectare. While the present study evaluates the effect of feeding management on cow performance, a reduction in profitability is observed when compared with the CTL FT. Without increases in stocking rates these systems should not be practiced at farm level.

\section{CONCLUSIONS}

The objective of this study was to simulate an economic appraisal of $2 \mathrm{GG}$ of HF dairy cows of divergent EBI across 3 contrasting spring-calving pasture-based FT using the MDSM, a stochastic budgetary simulation model integrating biological data obtained from a 4-yr experiment conducted during 2013 to 2016. The outcome of the current analysis and the Next Generation Study as a whole validated that EBI delivers substantially improved cow performance and profit per cow, per hectare, and whole farm profit, within the constraints of intensive seasonal calving pasture-based production. It demonstrated the resilience of high-EBI 
genetics within the context of contrasting seasonal pasture-based feeding systems and in the face of varying milk or concentrate price. From an international perspective, the study clearly demonstrated the power of a suitably constructed index together with a wellconsidered breeding program to make considerable favorable change (i.e., deliver both highly productive and highly fertile genetics) over a relatively short duration. This study has shown that, in the context of current policy constraints, the EBI delivers increased profitability, which should be the fundamental objective of any breeding program. The process completed in this study should form the basis of a continued evaluation of the effect of the EBI at the farm level in Ireland and for other indices globally.

\section{ACKNOWLEDGMENTS}

The technical assistance of Ricki Fitzgerald and the diligent work of the farm staff at the Dairygold Research Farm are gratefully acknowledged. The authors have not stated any conflicts of interest.

\section{REFERENCES}

Bargo, F., L. D. Muller, J. E. Delahoy, and T. W. Cassidy. 2002. Milk response to concentrate supplementation of high producing dairy cows grazing at two pasture allowances. J. Dairy Sci. 85:17771792. https://doi.org/10.3168/jds.S0022-0302(02)74252-5.

Bargo, F., L. D. Muller, E. S. Kolver, and J. E. Delahoy. 2003. Invited review: Production and digestion of supplemented dairy cows on pasture. J. Dairy Sci. 86:1-42. https://doi.org/10.3168/jds.S0022 -0302(03)73581-4.

Coffey, E. L., L. Delaby, C. Fleming, K. M. Pierce, and B. Horan. 2018. Multi-year evaluation of stocking rate and animal genotype on milk production per hectare within intensive pasture-based production systems. J. Dairy Sci. 101:2448-2462. https://doi.org/10 $.3168 /$ jds.2017-13632.

Cole, J. B., and P. M. Van Raden. 2018. Symposium review: Possibilities in an age of genomics: The future of selection indices. J. Dairy Sci. 101:3686-3701.

Delaby, L., F. Buckley, N. McHugh, and F. Blanc. 2018. Robust animals for grass based production systems. Sustainable meat and milk production from grasslands. Pages 389-400 in Proc. 27th General Meeting of the European Grassland Federation, Cork, Ireland. European Grassland Federation EGF, Zürich, Switzerland.

Dillon, P., T. Hennessy, L. Shalloo, F. Thorne, and B. Horan. 2008. Future outlook for the Irish dairy industry: A study of international competitiveness, influence of international trade reform and requirement for change. Int. J. Dairy Technol. 61:16-29. https:// doi.org/10.1111/j.1471-0307.2008.00374.x.

Dillon, P., J. R. Roche, L. Shalloo, and B. Horan. 2005. Optimising financial returns from grazing in temperate pastures. Pages 131-147 in Utilisation of Grazed Grass in Temperate Animal Systems. Workshop of the 20th International Grassland Congress. J. J. Murphy, ed. Wageningen Academic Publishers, Wageningen, the Netherlands.

Dohme-Meier, F., L. D. Kaufmann, S. Görs, P. Junghans, C. C. Metges, H. A. Van Dorland, R. M. Bruckmaier, and A. Münger. 2014 Comparison of energy expenditure, eating pattern and physical activity of grazing and zero-grazing dairy cows at different time points during lactation. Livest. Sci. 162:86-96. https://doi.org/10 .1016/j.livsci.2014.01.006.
Esslemont, R., M. Kossaibati, and J. Allcock. 2001. Economics of fertility in dairy cows. Pages 5-15 in Recording and Evaluation of Fertility Traits in UK Dairy Herds. SAC (Scottish Agricultural College), Edinburgh Scotland.

Evans, R. D., P. Dillon, F. Buckley, D. P. Berry, M. Wallace, V. Ducrocq, and D. J. Garrick. 2006a. Trends in milk production, calving rate and survival of cows in 14 Irish dairy herds as a result of the introgression of Holstein-Friesian genes. Anim. Sci. 82:423-433. https://doi.org/10.1079/ASC200660.

Evans, R. D., P. Dillon, L. Shalloo, M. Wallace, and D. J. Garrick. 2004. An economic comparison of dual-purpose and Holstein-Friesian cow breeds in a seasonal grass-based system under different milk production scenarios. Ir. J. Agric. Food Res. 43:1-16.

Evans, R. D., M. Wallace, L. Shalloo, D. J. Garrick, and P. Dillon. 2006b. Financial implications of recent declines in reproduction and survival of Holstein-Friesian cows in spring-calving Irish dairy herds. Agric. Syst. 89:165-183. https://doi.org/10.1016/j.agsy .2005.08.008.

Geary, U., N. Lopez-Villalobos, D. J. Garrick, and L. Shalloo. 2010. Development and application of a processing model for the Irish dairy industry. J. Dairy Sci. 93:5091-5100. https://doi.org/10 .3168/jds.2010-3487.

Hanrahan, L., A. Geoghegan, M. O’Donovan, V. Griffith, E. Ruelle, M. Wallace, and L. Shalloo. 2017. PastureBase Ireland: A grassland decision support system and national database. Comput. Electron. Agric. 136:193-201. https://doi.org/10.1016/j.compag .2017.01.029.

Hanrahan, L., N. McHugh, T. Hennessy, B. Moran, R. Kearney, M. Wallace, and L. Shalloo. 2018. Factors associated with profitability in pasture-based systems of milk production. J. Dairy Sci. 101:5474-5485. https://doi.org/10.3168/jds.2017-13223.

Holmes, C., I. Brookes, D.J. Garrick, D.D.S. Mackenzie, T. Parkinson, and G.F. Wilson. 2002. Milk Production from Pasture Principles and Practices, millennium ed. Masse University, Palmerstown North, New Zealand.

Hurtado-Uria, C., D. Hennessy, L. Shalloo, R. Schulte, L. Delaby, and D. O'Connor. 2013. Evaluation of three grass growth models to predict grass growth in Ireland. J. Agric. Sci. 151:91-104. https:// doi.org/10.1017/S0021859612000317.

ICBF. 2018. The Role of the DAIRY G€N€ IR€LAND Programme. Irish Cattle Breeding Federation. Accessed Aug. 13, 2020. https:/ /www.icbf.com/wp/?p=9750

Jarrige. R. 1989. Ruminant Nutrition: Recommended Allowances and Feed Tables. INRA, Paris, France.

Keane, M., and D. O'Connor. 2009. Price Volatility in the EU Dairy Industry: Causes, Consequences and Coping Mechanisms. European Dairy Association, Brussels.

Kolver, E. S., and P. A. Hedley. 2006. Achieving high performance from a range of farm systems in the South Island. Pages 141-167 in Proc. South Island Dairy Event 6, New Zealand. Lincoln University, Canterbury, New Zealand.

Lopez-Villalobos, N., D. J. Garrick, C. W. Holmes, H. T. Blair, and R. J. Spelman. 2000. Profitabilities of some mating systems for dairy herds in New Zealand. J. Dairy Sci. 83:144-153. https://doi.org/ 10.3168/jds.S0022-0302(00)74865-X.

Loughrey, J., F. Thorne, A. Kinsella, T. Hennessy, C. O'Donoghue, and X. Vollenweider. 2015. Market risk management and the demand for forward contracts among Irish dairy farmers. Int. J. Agric. Manage. 4:173-180.

Lucy, M. C. 2001. Reproductive loss in high-producing dairy cattle: Where will it end? J. Dairy Sci. 84:1277-1293. https://doi.org/10 .3168/jds.S0022-0302(01)70158-0.

Macdonald, K. A., G. A. Verkerk, B. S. Thorrold, J. E. Pryce, J. W. Penno, L. R. McNaughton, L. J. Burton, J. A. S. Lancaster, J. H. Williamson, and C. W. Holmes. 2008. A Comparison of three strains of Holstein-friesian grazed on pasture and managed under different feed allowances. J. Dairy Sci. 91:1693-1707. https://doi .org/10.3168/jds.2007-0441.

McCarthy, B., L. Delaby, K. M. Pierce, A. Brennan, and B. Horan. 2013. The effect of stocking rate and calving date on milk pro- 
duction of Holstein-Friesian dairy cows. Livest. Sci. 153:123-134. https://doi.org/10.1016/j.livsci.2013.01.013.

McCarthy, S., B. Horan, P. Dillon, P. O'Connor, M. Rath, and L. Shalloo. 2007. Economic comparison of divergent strains of Holstein-Friesian cows in various pasture-based production systems. J. Dairy Sci. 90:1493-1505. https://doi.org/10.3168/jds.S0022 -0302(07)71635-1.

McEvoy, M., E. Kennedy, J. P. Murphy, T. M. Boland, L. Delaby, and M. O'Donovan. 2008. The effect of herbage allowance and concentrate supplementation on milk production performance and dry matter intake of spring-calving dairy cows in early lactation. J. Dairy Sci. 91:1258-1269. https://doi.org/10.3168/jds.2007-0710.

Miglior, F., A. Fleming, F. Malchiodi, L. F. Brito, P. Martin, and C. F. Baes. 2017. A 100-Year Review: Identification and genetic selection of economically important traits in dairy cattle. J. Dairy Sci. 100:10251-10271.

Miglior, F., B. L. Muir, and B. J. Van Doormaal. 2005. Selection indices in Holstein Cattle of various countries. J. Dairy Sci. 88:12551263. https://doi.org/10.3168/jds.S0022-0302(05)72792-2.

Minchin, W.. F. Buckley, D. A. Kenny, M. G. Keane, L. Shalloo, and M. O'Donovan. 2009. Prediction of cull cow carcass characteristics from liveweight and body condition score measured pre slaughter. Ir. J. Agric. Food Res. 48:75-86.

O'Brien, D., B. Moran, and L. Shalloo. 2018. A national methodology to quantify the diet of grazing dairy cows. J. Dairy Sci. 101:85958604. https://doi.org/10.3168/jds.2017-13604.

O'Donovan, M. 2000. The relationship between the performance of dairy cows and grassland management on intensive dairy farms in Ireland. PhD Thesis, Animal Science, University College Dublin, Dublin, Ireland.

O'Donovan, M., E. Lewis, and P. O'Kiely. 2011. Requirements of future grass-based ruminant production systems in Ireland. Ir. J. Agric. Food Res. 50:1-21.

O'Sullivan, M., S. T. Butler, K. M. Pierce, K. O'Sullivan, M. Crowe, and F. Buckley. 2020. Reproductive efficiency and survival of Holstein-Friesian cows of divergent Economic Breeding Index, evaluated under seasonal calving pasture-based management. J. Dairy Sci. 103:1685-1700.

O'Sullivan, M., P. Dillon, K. O'Sullivan, K. M. Pierce, N. Galvin, and F. Buckley. 2019b. Intake, efficiency, and feeding behavior characteristics of Holstein-Friesian cows of divergent Economic Breeding Index evaluated under contrasting pasture-based feeding treatments. J. Dairy Sci. 102:8234-8246. https://doi.org/10.3168/ jds.2019-16371.

O'Sullivan, M., B. Horan, K. M. Pierce, S. McParland, K. O'Sullivan, and F. Buckley. 2019a. Milk production of Holstein-Friesian cows of divergent Economic Breeding Index evaluated under seasonal pasture-based management. J. Dairy Sci. 102:2560-2577. https:// doi.org/10.3168/jds.2018-15559.

Plaizier, J. C., G. J. King, J. C. Dekkers, and K. Lissemore. 1997. Estimation of economic values of indices for reproductive performance in dairy herds using computer simulation. J. Dairy Sci. 80:27752783. https://doi.org/10.3168/jds.S0022-0302(97)76240-4.

Prendiville, R., L. Shalloo, K. M. Pierce, and F. Buckley. 2011. Comparative performance and economic appraisal of Holstein-Friesian,
Jersey and Jersey x Holstein-Friesian cows under seasonal pasturebased management. Ir. J. Agric. Food Res. 50:123-140.

Ramsbottom, G., A. R. Cromie, B. Horan, and D. P. Berry. 2012. Relationship between dairy cow genetic merit and profit on commercial spring calving dairy farms. Animal 6:1031-1039. https:// doi.org/10.1017/S1751731111002503.

Schmidt, G. H. 1989. Effect of length of calving intervals on income over feed and variable costs. J. Dairy Sci. 72:1605-1611. https:// doi.org/10.3168/jds.S0022-0302(89)79272-9.

Shadbolt, N. M. 2008. Strategic management of farm businesses: The role of strategy tools with particular reference to the balanced scorecard. J. Farm Manag. 13:205-218.

Shadbolt, N. M. 2012. Competitive strategy analysis of NZ pastoral dairy farming systems. Int. J. Agric. Manage. 1:19-27.

Shalloo, L., P. Creighton, and M. O'Donovan. 2011. The economics of reseeding on a dairy farm. Ir. J. Agric. Food Res. 50:113-122.

Shalloo, L., A. Cromie, and N. McHugh. 2014. Effect of fertility on the economics of pasture-based dairy systems. Animal 8(Suppl.1):222-231. https://doi.org/10.1017/S1751731114000615.

Shalloo, L., P. Dillon, M. Rath, and M. Wallace. 2004a. Description and validation of the Moorepark Dairy System Model. J. Dairy Sci. 87:1945-1959. https://doi.org/10.3168/jds.S0022-0302(04)73353 -6 .

Shalloo, L., J. Kennedy, M. Wallace, M. Rath, and P. Dillon. 2004b. The economic impact of cow genetic potential for milk production and concentrate supplementation level on the profitability of pasture based systems under different EU milk quota scenarios. J. Agric. Sci. 142:357-369. https://doi.org/10.1017/S002185960400437X.

Sheahan, A. J., E. S. Kolver, and J. R. Roche. 2011. Genetic strain and diet effects on grazing behavior, pasture intake, and milk production. J. Dairy Sci. 94:3583-3591. https://doi.org/10.3168/jds .2010-4089.

Van Vuuren, A., and A. Van den Pol-van Dasselaar. 2006. Grazing systems and feed supplementation. Pages 85-101 in Fresh Herbage for Dairy Cattle: The Key to a Sustainable Food Chain. Springer, New York, NY.

Veerkamp, R. F., P. Dillon, E. Kelly, A. R. Cromie, and A. F. Groen. 2002. Dairy cattle breeding objectives combining yield, survival and calving interval for pasture-based systems in Ireland under different milk quota scenarios. Livest. Prod. Sci. 76:137-151. https: //doi.org/10.1016/S0301-6226(02)00006-4.

Washburn, S. P., and K. A. E. Mullen. 2014. Invited review: Genetic considerations for various pasture-based dairy systems. J. Dairy Sci. 97:5923-5938. https://doi.org/10.3168/jds.2014-7925.

Wolf, C. A., and N. J. Olynk Widmar. 2014. Adoption of milk and feed forward pricing methods by dairy farmers. J. Agric. Appl. Econ. 46:527-541. https://doi.org/10.1017/S1074070800029084.

\section{ORCIDS}

M. O’Sullivan (®) https://orcid.org/0000-0002-8758-4496

L. Shalloo ( ) https://orcid.org/0000-0003-1714-672X

K. M. Pierce @ https://orcid.org/0000-0002-2056-6189 